\title{
YEARLY AND OPERATION PLANNING OF THE IRRIGATION REGIMES OF THE MAIN CROPS
}

\section{Pysarenko P. V.}

\section{INTRODUCTION}

Irrigated agriculture is a complex multifunctional system in which the main role is played by soil fertility, structure of sown areas, genetic characteristics of varieties, their adaptability to the conditions of cultivation, organic and mineral fertilizers, plant protection products, modern technologies of crops cultivation, etc. ${ }^{1,2}$. The use of scientifically substantiated components of the system of agriculture on the irrigated lands ensures and optimizes the use of natural factors and, first of all, water resources $^{3}$. An important element in these interrelated factors is the irrigation regime, the main task of which is to enhance the effects of other factors in the direction of obtaining high yield and pure profit from irrigation ${ }^{4,5}$.

In the practice of irrigated agriculture, several methods are used to determine the time and norms of vegetation watering, which differ in the degree of reliability, the labor-intensiveness of gathering information, the expenses of time and cost for the obtaining of the necessary results ${ }^{6}$. However, the use of any of the methods provides more reliable data than the irregular use of irrigation according to general recommendations ${ }^{7}$.

\footnotetext{
${ }^{1}$ Авдеев Ю. И. Рекомендации по возделыванию сельскохозяйственных культур при капельном орошении. М.: Изд. МСХ РФ, 2003. 46 с.

${ }^{2}$ Балюк С. А., Ромащенко М. І. Наукові аспекти сталого розвитку зрошення земель в Україні. К. : ДІА, 2006. 32 с.

${ }^{3}$ Писаренко П. В., Вожегова Р. А., Лавриненко Ю. О., Коковіхін С. В. Вимоги сільськогосподарських культур до режиму зрошення. Посібник украӥнського хлібороба. 2011. C. 95-100.

${ }^{4}$ Жовтоног О. І., Філіпенко Л. А., Шостак І. К., Поліщук В. В. Сучасна концепція та методи управління зрошенням на рівні господарства в умовах недостатнього зволоження. Наукові основи землеробства в умовах недостатнього зволоження. К., 2001. С. 89-92.

5 Жуйков Г. Є. Економічні засади ведення землеробства на зрошуваних землях. Херсон : Айлант, 2003. 288 с.

${ }^{6}$ Кириенко Т. Н., Остапчик В. П., Жовтоног О. И. Основные принципы разработки почвозащитных режимов орошения. Орошаемые черноземы и их рациональное использование. Новочеркасск: НПО «Мелиорация», 1990. С. 85-92.

7 Латифов Н. Л., Кобозев И. В., Парахин Н. В. Оптимизация режимов орошения сельскохозяйственных культур. М. : МСХА, 1996. 94 с.
} 
The South of Ukraine has lost its status as a new irrigation area long ago, because in this region for the last half of a century a large number of special studies have been conducted to determine the actual moisture uptake by phytocenosis by the scientific institutions, and first of all, Institute of Irrigated Agriculture of NAAS ${ }^{8}$.

\section{Formation of the actual irrigation regime of crops depending on the natural and economic conditions of farms}

Irrigation regime is one of the key elements of the system of irrigated agriculture and crop cultivation technology. This is a complex indicator that consists of determination and distribution in time of the number and norms of watering for crops in dependence on their biological characteristics, the reaction to the lack of moisture at different stages of plant organogenesis, meliorative conditions of the irrigated areas, irrigation water quality, irrigation methods, climate of the zone and weather conditions of the vegetative period ${ }^{9}$. Irrigation regime should provide an optimization of the water regime of soil and phytoclimate of crops, exclusion of gravitational losses of water beyond the active soil layer, promotion of the most complete use of the bioclimatic potential of the zone and soil fertility, genetic capabilities of varieties, fertilizers, and plant protection products, etc. In modern amelioration and agricultural science and practice, several approaches are applied to the formation of irrigation regimes, which are combined into following types of irrigation regimes: optimal, water-saving and soil-protective ${ }^{10}$.

The optimal irrigation regimes are directed to the continuous supply of plants with water throughout the whole vegetation by maintaining the optimal soil moisture through irrigation and creating the conditions for realizing the potential level of water consumption of the crop $^{3}$. While observing the whole range of technological measures for cultivation of crops and environmental requirements for the volumes of irrigation norms on a specific irrigated array, optimal irrigation regimes guarantee the maximum yield addition due to the irrigation and elimination of irrigation water losses

\footnotetext{
${ }^{8}$ Льгов Г. К., Адиньяев Э. Д. Водопотребление и режим орошения кукурузы. Агробиологическое обоснование поливного режима и применение удобрений под кукурузу. Тр. Горского СХИ. 1974. С. 3-37.

${ }_{9}$ Методические указания по применению биофизического метода для определения эффективных запасов влаги в почве м сроков полмва сельскохозяйственных культур. Херсон: $1975.77 \mathrm{c}$.

${ }^{10}$ Писаренко В. А., Коковіхін С. В., Іванов І. Т., Тищенко О. П., Мішукова Л. С. та ін. Методичні рекомендації по застосуванню водозберігаючих режимів зрошення сільськогосподарських культур. Херсон : Айлант, 2002. 32 с.
} 
for infiltration beyond the root-containing soil layer ${ }^{11}$. In the recent past, these irrigation regimes have been major ones in the irrigated agriculture of Ukraine. Currently, they are mainly used in farms that are sufficiently provided with financial, water and material and technical resources and plan to receive the highest yields from the whole area or its part where the most economically profitable crops are cultivated ${ }^{8}$.

Water-saving irrigation regimes, developed at the Institute of Irrigated Agriculture under the leadership of V.A. Pysarenko, together with the specialists of the Institute of Water Problems and Land Reclamation of the NAAS, nowadays are the main type of irrigation regime that is being introduced into production ${ }^{12,13,14}$.

The theoretical concept of water-saving irrigation regimes is based on the analysis of long-term research on the questions of crop irrigation, which shows that there is a disproportionate dependence between the level of plant yield, total water consumption and irrigation rate. Increase in yield per unit of irrigation water increases with irrigation rate to a certain limit, and further decreases and even reaches zero or negative values. Thus, the share of individual irrigation in the formation of additional yield from irrigation is not equal and this must be taken into account in practical activities ${ }^{8,12}$.

The Institute of Irrigated Agriculture has conducted for many years researches on 4 irrigation systems (Ingulets, Danube-Dnistrovsk, Rozdolnenska and Frunzenska) concerning the comparison of the efficiency of the application of optimal and water-saving irrigation regimes (Table 1). These irrigation systems differ in the quality of irrigation water, the physical and chemical properties of soils and the climate, as they are located in different zones of the Steppe. Therefore, the results of the studies are representative for the entire Steppe region. They indicate that the use of water-saving irrigation regimes provides a significant reduction in irrigation water expenditures for all crops at insignificant yield losses, compared to optimal irrigation. In the conditions of Southern Steppe, cereals, soybean, alfalfa and potato, which at the decrease of the irrigation norm by

11 Писаренко В. А. Методичні підходи до формування водозберігаючих режимів зрошення культур у степовому регіоні. Наукові основи землеробства в умовах недостатнього зволоження: Матер. наук.-практ. конф. 21-23 лютого 2000 р. К.: Аграрна наука, 2001. С. 181-189.

Писаренко В. А. Особливості планування режимів зрошення сільськогосподарських культур в умовах дефіциту водно-енергетичних ресурсів. Актуальні проблеми ефективного використання зрошуваних земель. Сб. наук. праць ін-т. зрошув. землер. Херсон, 1999. № 2. С. 8-12.

${ }_{13}$ Розгон В. А. Оптимізація водного балансу зрошуваних територій. Зрошуване землеробство. 2002. №3. С. 87.

${ }_{14}$ Ромащенко М. І., Балюк С. А. Зрошення земель в Україні. Стан та шляхи поліпшення. К. : Світ, 2000. $114 \mathrm{c.}$ 
19.1-41.8\% almost do not lose their yields, react most positively to the application of water-saving regimes of irrigation.

Soil-protective regimes of irrigation are applied in case of poor meliorative, ecological and soil conditions of the irrigated array ${ }^{15,16}$.

Table 1

Comparative evaluation of different types of irrigation regimes on the studied areas (the materials of the Department of Irrigated Agriculture of the Institute of Irrigated Agriculture of NAAS)

\begin{tabular}{|c|c|c|c|c|c|}
\hline \multirow{2}{*}{$\begin{array}{c}\text { Crop and a } \\
\text { number of the } \\
\text { years of the } \\
\text { study }\end{array}$} & \multirow{2}{*}{$\begin{array}{c}\text { Irigation } \\
\text { regime model }\end{array}$} & \multirow{2}{*}{$\begin{array}{c}\text { Average } \\
\text { irrigation } \\
\text { norm, } \\
\text { m}^{3} / \mathbf{h a}\end{array}$} & \multirow{2}{*}{$\begin{array}{c}\text { Yield, } \\
\text { t/ha }\end{array}$} & \multicolumn{2}{|c|}{$\begin{array}{l}\text { The ratio of water- } \\
\text { saving irrigation indexes } \\
\text { to the optimal one, } \%\end{array}$} \\
\hline & & & & $\begin{array}{c}\text { Decrease } \\
\text { of yield }\end{array}$ & $\begin{array}{l}\text { Water } \\
\text { saving }\end{array}$ \\
\hline \multirow{2}{*}{$\begin{array}{c}\text { Winter wheat } \\
\text { (9) }\end{array}$} & Optimal & 1605 & 5.68 & & \\
\hline & Water-saving & 1317 & 5.76 & +1.4 & 19.9 \\
\hline \multirow{2}{*}{$\begin{array}{l}\text { Corn for grain } \\
\text { (16) }\end{array}$} & Optimal & 2220 & 9.46 & & \\
\hline & Water-saving & 1520 & 9.09 & 3.9 & 31.5 \\
\hline \multirow{2}{*}{ Soybean (6) } & Optimal & 2840 & 3.27 & & \\
\hline & Water-saving & 2450 & 3.25 & 0.6 & 13.7 \\
\hline \multirow{2}{*}{ Sugar-beet (9) } & Optimal & 2470 & 64.4 & & \\
\hline & Water-saving & 1930 & 61.9 & 3.9 & 22.1 \\
\hline \multirow{2}{*}{$\begin{array}{c}\text { Alfalfa for } \\
\text { green forage } \\
\text { for three years } \\
\text { of the use ( } 3 \\
\text { cycles) }\end{array}$} & Optimal & 9800 & 152.6 & & \\
\hline & Water-saving & 6860 & 145.3 & 4.8 & 30.0 \\
\hline \multirow{2}{*}{$\begin{array}{l}\text { Alfalfa for } \\
\text { green forage } \\
\text { for three years } \\
\text { of the use }(7)\end{array}$} & Optimal & 4490 & 66.2 & & \\
\hline & Water-saving & 2890 & 63.7 & 3.8 & 35.6 \\
\hline \multirow{2}{*}{ Mangel (8) } & Optimal & 3300 & 159.8 & & \\
\hline & Water-saving & 2700 & 152.9 & 4.3 & 18.2 \\
\hline \multirow{2}{*}{$\begin{array}{c}\text { Corn for silage } \\
\text { (9) }\end{array}$} & Optimal & 1990 & 74.6 & & \\
\hline & Water-saving & 1640 & 74.2 & 0.5 & 17.6 \\
\hline \multirow{2}{*}{$\begin{array}{c}\text { Early potato } \\
(6)\end{array}$} & Optimal & 1800 & 23.4 & & \\
\hline & Water-saving & 1420 & 23.3 & 0.4 & 20.6 \\
\hline
\end{tabular}

They differ in economy of irrigation and on the background of other agro-ameliorative measures for conservation and recovery of soil fertility perform soil-protective function and ensure the balance of natural processes in agro-ecological systems.

15 Ромащенко М. І., Жовтоног О. І., Філіпенко Л. А., Деменкова Т. Ф. Методика планування оптимальних екологічно безпечних режимів зрошення. К. : УкрНИИГиМ, 1997. C. 43.

${ }_{16}$ Справочная книга по орошаемому земледелию. Общая ред.: Погребняк А.П., Калашников К.Г. Кишинев: Картя Молдовеняскэ. 1990. 134 с. 
In accordance with the direction and quantitative characteristics of changes in soil and ecological conditions of land under soil-protective regimes of irrigation, it is proposed to apply limits on irrigation rates, terms of their application and quality of irrigation water. As concerning the irrigation limits, they should only humidify the soil layer in which the most quantity of roots is concentrated. The terms of irrigation, in general, should be planned for the critical periods of plant development, when the maximum yield from their use is observed. Of course, degraded soils should be discarded from the use of low quality irrigation water. Comparing the requirements for soil-protective and water-saving irrigation regimes, they are the same in many parameters they and, therefore, the latter can be applied to degraded soils, under the condition of application of some adjustments.

Thus, it is practically impossible to find an alternative to the watersaving model of the crop irrigation regime in the current economic conditions. Formation of a regime of irrigation of a specific crop is divided into two stages: norms;

- the first - preliminary planning of terms, watering and irrigation

- second - the operation management of the irrigation regime during the irrigation season, taking into account the initial moisture reserves, weather conditions of the vegetation period, the tempo of plant development and other parameters.

The first stage, which is carried out before the beginning of the irrigation season, is directed to the obtaining information on the total requirements for irrigation water during the irrigation season, as well as on its separate periods, for ordering it in water economy institutions. Mostly, calculations are made for a moderately dry year (75\% of supply) for a particular crop, and then the results are united for the crop rotation on the whole. In the modern conditions, these calculations need to be linked with the cost of electricity during the day and should be corrected to maximize the reduction in expenditures per the hectare of irrigation. Under conduction of the work concerning irrigation regime planning, it is necessary to determine the type of irrigation regime, which is meeting most closely the irrigation management strategy or the meliorative conditions of the irrigated array.

An aggregate index of irrigation regime is the irrigation norm or the total amount of irrigation water that has to be applied to the fields to overcome soil moisture deficit and to create optimal conditions for the water supply of plants. Planning irrigation regimes, it is possible to use the materials of Table 2, which contains the project parameters of irrigation norms of crops by the water-saving type of irrigation regime for the moderately dry years.

Irrigation norm consists of the norms of different types of watering (water-supplying, pre-sowing, seedling-provoking, vegetative, refreshing, 
etc.), but the most common ones are water-supplying, pre-sowing, postsowing and vegetative.

Water-supplying watering is conducted to create soil moisture reserve in the autumn period and reduce the need for vegetative watering in the spring and summer.

Pre-sowing (pre-planting) watering has a much larger range of application, they are carried out under winter crops, post-mowing and postharvest crops, under the potato of summer planting, at planting of seedlings of vegetable crops, etc. The main purpose of these watering is to obtain on time germination (seedlings striking roots) and the normal development of plants at the beginning of vegetation. In this connection, irrigation norms of pre-sowing watering are small, mostly $200-300 \mathrm{~m}^{3} /$ ha and can be applied in the areas with different groundwater level. At deep groundwater level their norm can be increased up to $500 \mathrm{~m}^{3} / \mathrm{ha}$.

Table 2

Project irrigation norms under the water-saving irrigation regimes for the areas with different groundwater levels in the moderately dry years

\begin{tabular}{|c|c|c|c|c|}
\hline \multirow{2}{*}{ Crop } & \multirow{2}{*}{$\begin{array}{c}\text { Group of } \\
\text { ripeness }\end{array}$} & $\mathbf{1 . 0 - 1 . 5}$ & $\mathbf{2 . 0 - 2 . 5}$ & $\begin{array}{c}\text { Geeper } \\
\text { than 3.0 }\end{array}$ \\
\cline { 3 - 5 } & all & $95-100$ & $120-145$ & $160-180$ \\
\hline Winter wheat & all & $75-85$ & $90-105$ & $110-130$ \\
\hline Winter barley & all & $50-60$ & $65-80$ & $80-100$ \\
\hline Spring barley & $\begin{array}{c}\text { Middle-early and } \\
\text { middle }\end{array}$ & $80-90$ & $120-135$ & $160-180$ \\
\cline { 3 - 5 } Corn for grain & middle-late & $95-110$ & $145-165$ & $190-220$ \\
\hline \multirow{2}{*}{$\begin{array}{c}\text { Alfalfa under the cover of } \\
\text { corn for green forage }\end{array}$} & all & $90-105$ & $145-175$ & $220-270$ \\
\hline \multirow{2}{*}{$\begin{array}{c}\text { Alfalfa of the past years: } \\
\text { second }\end{array}$} & all & - & $170-190$ & $280-310$ \\
\hline third & all & - & $130-150$ & $220-250$ \\
\hline Corn for silage & middle-late & $95-110$ & $145-165$ & $190-220$ \\
\hline \multirow{2}{*}{ Soybean } & early & $90-95$ & $120-130$ & $160-190$ \\
\cline { 2 - 5 } & middle & $100-110$ & $135-145$ & $200-220$ \\
\hline Sugar-beet and mangel & all & $110-125$ & $170-195$ & $240-280$ \\
\hline \multirow{2}{*}{ Potato } & early & $90-95$ & $120-130$ & $150-160$ \\
\cline { 2 - 5 } & middle & $100-110$ & $135-145$ & $170-180$ \\
\cline { 2 - 5 } & late & $120-130$ & $160-175$ & $200-220$ \\
\hline Tomato & middle & $125-145$ & $175-200$ & $220-225$ \\
\hline
\end{tabular}

Post-sowing (seedling-provoking) and after-planting watering is used to improve the striking of roots by the seedlings of vegetable crops, the potato of summer planting, on post-mowing and post-harvest crops, which are sown in dry soil. In some cases, such watering is carried out on winter crops, 
especially at late sowing periods, as well as on the crops of vegetable and late spring crops, where there is rapid drying of the sowing layer of soil and it is not possible to obtain qualitative seedlings. Post-sowing and postplanting watering humidify the soil to the depth of 15-20 centimeters with small norms (200-250 m3/ha) that makes it possible to avoid the formation of a dense soil crust, especially on heavy alkaline soils.

Vegetative watering for most crops play a major role in the formation of high yields, as well as obtaining additional products from irrigation, as they are carried out, because they are mainly conducted in the summer months during the maximum requirements of plants in easily accessible moisture. Under the planning of terms of vegetative watering, it is necessary to take into account the reaction of plants to the conditions of moisture during the vegetation. Crops have a periods of the vegetation when they are tolerant to the lack of moisture in the formation of crops and those, in which the worsening of the water regime of the soil has a negative effect on the productivity of plants. Such periods of vegetation are called critical periods and during them it is necessary to withstand intensive water supply of plants at the expense of irrigation (Table 3 ).

Intensive water supply of plants is achieved under the conditions of vegetative watering at the optimum humidity of the calculated soil layer. This index is largely determined by the physical properties of different soils and averages to: on light clays $80-85 \%$, on heavy loam $75-80 \%$, on medium loam $65-70 \%$, on light loam $60-65 \%$ of WC and on sandy loam $50-60 \%$ of the water-holding capacity (WC).

At the application of water-saving irrigation regimes in the interphase periods, which come sooner or later than the critical period, it is recommended to appoint watering at the moisture level by $5-10 \% \mathrm{WC}$ below the optimum for this type of soil. Such a decrease in pre-irrigation soil moisture, in most years (excepting the extremely dry ones), does not affect crop yields.

Perenial studies determined that the optimal pre-irrigation soil moisture is defined by the weather conditions of the vegetative period. In the years with cool weather, considerable number of days with rainfall and high humidity, vegetative watering, even during critical periods, can be appointed at the humidity by $5-10 \%$ lower than the optimum for this type of soil. In dry years, on the contrary, irrigation should be carried out at soil humidity by 5 $10 \%$ of WC higher than the optimum indexes and, first of all, during critical periods. 
Critical in water supply periods of plants development (by the materials of the Department of Irrigated Agriculture of the Institute of Irrigated Agriculture of NAAS)

\begin{tabular}{|c|c|}
\hline Crop & Critical period \\
\hline Winter and spring cereals & Stem elongation - grain formation \\
\hline Corn for grain & Before 10 days to taseling - 20 days after flowering \\
\hline Millet, sorghum, soriz & Panicle ejection - grain formation \\
\hline Soybean & Budding, flowering - grain formation \\
\hline Sunflower & Calathium formation - grain formation \\
\hline Sugar-beets & The period of intensive growth of leaves and root-crops \\
\hline Cornb for silage & 9-10 leaves - grain formation \\
\hline Alfalfa of the past years & Spring and after-mowing regrowth - budding \\
\hline Potato & Budding - beginning of leaves yellowing \\
\hline Tomato & Fruit inception and growth \\
\hline Cabbage & Formation of decumbent crown, ripening of heads \\
\hline Cucumber & Fruitage \\
\hline
\end{tabular}

At the determination of the terms and norms of vegetation watering, which are carried out by sprinkling or surface method, an important parameter is the depth of soil humidification (the estimated layer). Scientific studies show that the depth of soil humidification must be differentiated depending on the physical properties of the soil, the level of groundwater, the stages of plant development, the strength of their root systems, and so on. At a deep level of groundwater on the crops of perennial herbs, mangel and sugar-beets, cereals, corn, soybean and other crops with a well-developed root system, the estimated layer is, mostly, 0.5-0.7 m, and on annual herbs, potatoe, onions $-0.3-0.5 \mathrm{~m}$.

The irrigation norms of watering must meet the following conditions: provide humidification of the soil layer in which the main mass of the root system of plants is located, exclude gravitational losses of water outside the zone of active moisture exchange, and allow it to accumulate atmospheric precipitation, etc.

Under the water-saving regimes, special attention is paid to the terms of vegetative watering for individual crops, taking into account their biological features.

On the winter wheat, this question has been studied for a number of years at the deep groundwater level at the Ingulets irrigation system (Table 4).

The scheme of the experiment provided for the next terms of irrigation termination: 1 . autumn water-supplying; 2 . carrying out spring vegetative watering until the earing stage; 3 . carrying out spring vegetative watering 
until the stage of grain formation; 4. carrying out spring vegetative watering until the stage of milk ripeness of grain.

Table 4

Influence of the terms of vegetative watering termination on the irrigation water consumption and winter wheat productivity

\begin{tabular}{|c|c|c|c|c|c|}
\hline № & $\begin{array}{l}\text { Term of the } \\
\text { watering } \\
\text { termination }\end{array}$ & $\begin{array}{l}\text { Number of } \\
\text { watering }\end{array}$ & $\begin{array}{c}\text { Irrigation } \\
\text { norm, } \mathbf{m}^{3} / \mathbf{h a}\end{array}$ & $\begin{array}{c}\text { Grain } \\
\text { yield, t/ha }\end{array}$ & $\begin{array}{c}\text { Coefficient of } \\
\text { irrigation } \\
\text { efficiency, } \mathbf{m}^{3 / t}\end{array}$ \\
\hline 1 & No irrigation & - & - & 2.14 & - \\
\hline 2 & $\begin{array}{l}\text { Watering until } \\
\text { the earing }\end{array}$ & 1.7 & 750 & 5.84 & 1071 \\
\hline 3 & $\begin{array}{l}\text { Watering until } \\
\text { the grain } \\
\text { formation }\end{array}$ & 2 & 1000 & 6.36 & 820 \\
\hline 4 & $\begin{array}{c}\text { Watering until } \\
\text { the milk ripeness } \\
\text { of grain }\end{array}$ & 3 & 1500 & 6.80 & 904 \\
\hline \multicolumn{4}{|c|}{$\mathrm{LSD}_{05}, \mathrm{t} / \mathrm{ha}$} & 0.27 & \\
\hline
\end{tabular}

During the whole vegetation, watering was appointed by the moisture content of 0.5 meters layer of soil at $70 \%$ of the water-holding capacity. The years of the experiments conduction by temperature and rainfall were favorable for winter wheat cultivation, as it is testified by the indexes of the crop yield. For the years of the study it was found that the highest yield of the crop on the background of water-supplying watering was obtained under the conduction of it in the inter-stage period of spring regrowth - earing. Watering in the next stages significantly increases the productivity of plants, but the coefficient of irrigation efficiency is reduced. Certainly, this fact should be taken into account at planning the irrigation regime of the crop.

On drip irrigation systems, watering norms should take into account the area of humidification and the frequency of irrigation (daily, 2-3 days, a week, etc.). It is known that, depending on the physical properties of different soils, optimal conditions for the development of plants are created at the moisture content of $85-90 \%$ of the water-holding capacity in the estimated layer on heavy-loamy and middle-loamy soils. On light loamy and sandy soils such conditions are formed at the humidity of 70-80\% of WC. In this regard, in the case of drip irrigation, at these soil moisture indexes it is advisable to plan the start of vegetation watering or renew them after heavy rains, which moisten the estimated soil layer to the water-holding capacity. At the early stages of crops development, when average daily evaporation is insignificant, irrigation is usually carried out one time per week. During the critical periods of water consumption, at high temperatures and low 
humidity of air, when the average daily evaporation increases to 60-70 $\mathrm{m} 3 / \mathrm{ha}$ and the decreased water supply of plants leads to a significant crop losses, irrigation in the weather without rains should be carried out daily.

Of course, planning irrigation regimes is a painstaking work that requires time and certain knowledge. However, in the end, it has to provide the answer to the question - how much water should be ordered by the decades and for the irrigation season on the whole.

\section{Comparative characteristics of the ways and methods of the appointment of watering of the major crops}

The bioclimatic method of S.M. Alpatyev and the biophysical method of D.A. Shtoyko are the most widely spread in Ukraine. These methods worked out the regimes of irrigation under the design of construction and reconstruction of irrigation systems, drawing up plans for water use of farms, creating information and advisory systems for irrigation planning, etc.

To check the calculations of water consumption by crops by the average daily evaporation, as well as to establish with accordance to methodological recommendations by using the biophysical method of the Institute of Irrigated Agriculture and the bioclimatic method of the Institute of Water Problems and Land Reclamation of the National Academy of Agrarian Sciences of Ukraine, their comparative evaluation has been performed. By the perennial data of field experiments of the Institute of Irrigated Agriculture with many field crops beginning from the 60-ies years of the past century, actual parameters of irrigation regime at the optimum level of water supply of plants were determined.

Thus, according to the working hypothesis of the studies, a comparative evaluation of conventional and new estimation methods was carried out at the determination of the irrigation norm of alfalfa of the 2 nd year of use in separate years. The actual indexes of irrigation norms in the experiments of the Institute of Irrigated Agriculture under the regime of alfalfa irrigation in the variant with the appointment of vegetative watering according to the optimal indexes (75-80\% of WC) of soil moisture during the entire irrigation season were taken as a standard.

The calculations took into account the parameters of the beginning of spring regrowth of the plants and the date of the last watering of alfalfa in a particular year. At the spring regrowth of plants, a deficit of moisture in the estimated soil layer $(0.7 \mathrm{~m})$ was determined each year. The calculations were performed according to the well-known methodological guidelines for determination of the water consumption by alfalfa plants. 
In this, the calculated terms of vegetation watering were not taken into account - only the actual and calculated irrigation norms were compared. Rainfall, average daily temperature, relative humidity and humidity deficiency of air were determined by the materials of Kherson Agrometeorological Station, near which during all the years the field experiments with alfalfa were carried out (Table 5).

Table 5

\section{Comparative assessment of thevalues of irrigation norms of alfalfa in} the second year of its life, calculated by different methods

\begin{tabular}{|c|c|c|c|c|c|c|c|c|c|c|c|}
\hline \multirow{3}{*}{ № } & \multirow{3}{*}{ Year } & \multirow{3}{*}{ 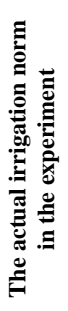 } & \multicolumn{3}{|c|}{$\begin{array}{l}\text { According to the } \\
\text { average daily } \\
\text { evaporation }\end{array}$} & \multicolumn{3}{|c|}{$\begin{array}{l}\text { Biophysical of the } \\
\text { Institute of Irrigated } \\
\text { Agriculture }\end{array}$} & \multicolumn{3}{|c|}{$\begin{array}{l}\text { Bioclimatic of the } \\
\text { Institute of Water } \\
\text { Problems and Land } \\
\text { Reclamation }\end{array}$} \\
\hline & & & \multirow{2}{*}{ हू } & \multicolumn{2}{|c|}{$\begin{array}{c}\text { deviation } \\
\text { from the } \\
\text { actual } \\
\text { irrigation } \\
\text { norm } \\
\end{array}$} & \multirow{2}{*}{ 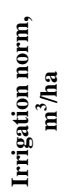 } & \multicolumn{2}{|c|}{$\begin{array}{c}\text { deviation } \\
\text { from the } \\
\text { actual } \\
\text { irrigation } \\
\text { norm }\end{array}$} & \multirow{2}{*}{ 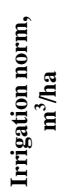 } & \multicolumn{2}{|c|}{$\begin{array}{c}\text { deviation from } \\
\text { the actual } \\
\text { irrigation } \\
\text { norm }\end{array}$} \\
\hline & & & & $\mathbf{m}^{3} / \mathbf{h a}$ & $\%$ & & $\mathrm{~m}^{3} / \mathbf{h a}$ & $\%$ & & $\mathrm{~m}^{3} / \mathbf{h a}$ & $\%$ \\
\hline \multicolumn{12}{|c|}{ Humid and moderately humid years } \\
\hline 1 & 1982 & 3550 & 3654 & +104 & 3 & 2889 & -661 & 19 & 2381 & $\begin{array}{c}- \\
1169\end{array}$ & 33 \\
\hline 2 & 1985 & 3300 & 3421 & +121 & 4 & 2596 & -704 & 21 & 2537 & -763 & 23 \\
\hline 3 & 1987 & 4900 & 4595 & -305 & 6 & 4137 & -763 & 16 & 3847 & $\begin{array}{c}- \\
1053\end{array}$ & 21 \\
\hline 4 & 1988 & 3150 & 3986 & +836 & 27 & 3563 & +413 & 13 & 3215 & +65 & 2 \\
\hline \multicolumn{2}{|c|}{$\begin{array}{l}\Sigma \text { for } 4 \\
\text { years }\end{array}$} & 3725 & 3914 & +189 & 5 & 3296 & -429 & 12 & 2995 & -730 & 20 \\
\hline \multicolumn{12}{|c|}{ Moderate years } \\
\hline 5 & 1969 & 5460 & 4422 & -1038 & 19 & 4293 & -1187 & 21 & 3831 & -1629 & 30 \\
\hline 6 & 1970 & 4952 & 4707 & -245 & 5 & 4415 & -537 & 11 & 3719 & -1233 & 25 \\
\hline 7 & 1983 & 4350 & 3896 & -454 & 10 & 3338 & -1012 & 23 & 2866 & -1484 & 33 \\
\hline 8 & 1984 & 4850 & 5365 & +515 & 11 & 5446 & +596 & 12 & 4454 & -396 & 8 \\
\hline \multicolumn{2}{|c|}{$\begin{array}{c}\Sigma \text { for } 4 \\
\text { years }\end{array}$} & 4903 & 4598 & -305 & 6 & 4373 & -530 & 11 & 3718 & -1185 & 24 \\
\hline \multicolumn{12}{|c|}{ Moderately dry and dry years } \\
\hline 9 & 1971 & 4959 & 4889 & -70 & 1 & 5612 & +663 & 13 & 4333 & -626 & 13 \\
\hline 10 & 1972 & 4842 & 5019 & +117 & 4 & 6787 & +1945 & 40 & 5368 & +526 & 11 \\
\hline 11 & 1986 & 4350 & 4729 & +379 & 9 & 5485 & +1135 & 26 & 4527 & +177 & 4 \\
\hline 12 & 1992 & 5100 & 5293 & +193 & 4 & 6064 & +964 & 19 & 4864 & -236 & 5 \\
\hline \multicolumn{2}{|c|}{$\begin{array}{c}\text { Average } \\
\text { for } 4 \text { years }\end{array}$} & 4813 & 4982 & +169 & 4 & 5987 & +1174 & 24 & 4773 & -40 & 1 \\
\hline \multicolumn{2}{|c|}{$\begin{array}{l}\text { Average } \\
\text { for } 12 \\
\text { years }\end{array}$} & 4480 & 4498 & +18 & 5 & 4552 & +72 & 2 & 3829 & -651 & 15 \\
\hline
\end{tabular}

*Note: The materials are generalized by the author with accordance to the reports, data of meteorological station. 
The analysis of the Table testifies that at the comparative evaluation of the estimation methods between themselves and with the instrumental method by soil moisture the average long-term data must not be used, as most researchers do, but we have to perform a comparison with the standard (in our case - with the actual irrigation norm) data of individual years. This approach allows obtaining reliable data on the evaluation of the efficiency of the application of one or another estimation method.

At the planning of the irrigation regime of any crop, we need to have data on moisture consumption in the average dry years (75\% of supply), and at the managing during the vegetation - to use the materials that simulate the weather conditions. Therefore, we provide comparative data on the efficiency of the estimation methods in the years of different provision with natural factors.

According to the performed studies, for an average of 12 years, all the estimation methods provided high accuracy in the determination of the irrigation norm, compared with the actual data in the field experiments. However, this is the result of smoothing the data by imposing differences with different signs $(+,-)$ over the years.

Other results were obtained at the grouping of the years with the same supply: in humid and moderately humid years, deviations in irrigation norms in the application of conventional estimation methods reached $12-20 \%$, in moderate years $-11-24 \%$, and in moderately dry and dry $-1-24 \%$.

The studies on the regime of irrigation of alfalfa in recent years show that under the optimal water supply, it provides the maximum yield. However, the reduction of irrigation norm by $10-15 \%$, nearly does not affect the yield level, especially in humid and moderate years.

For the 12 years of observations, conventional computational methods significantly cede to the new method, in which the irrigation norm error of $15 \%$ was observed twice (17\%). At the application of the bioclimatic method, this error ocurred 8 times (67\%) and at the biophysical one 6 times $(50 \%)$.

In the world practice of the determination of the moisture content of certain territories by estimation methods, the obtained figures are considered quite reliable if they have deviations from the balance-drier method indexes within $10-15 \%$ in any direction. Using this substantiation, we can conclude that fluctuations in the irrigation norm of $10-15 \%$ have virtually no effect on crop yields, which allowed us to take this indicator into account under the analysis of the obtained materials. At the same time, we consider it necessary to note that the increase of irrigation norm under the use of the estimation methods by $450-550 \mathrm{~m} 3 / \mathrm{ha}$ (on average by 1 watering) leads to 
an increase in the costs of agro- and energy resources for watering the crop with almost no increase in yield. On the contrary, reducing the irrigation norm by such a value, especially during the critical periods of plant development, can lead to a significant decrease in productivity. The analysis of the reliability of the calculated irrigation norms, compared with the actual in the experiments, gives the following results. For 18 years of the observations, well-known estimation methods within $15 \%$ of deviations provide: the biophysical method -11 years $(61 \%)$ and the bioclimatic one 12 years $(67 \%)$ of reliable results. The daily evaporation method provided 14 years $(78 \%)$ of the calculations within $\pm 15 \%$ of the deviations from the actual irrigation norms at the experimental plots. The proposed estimation method works quite clearly with sufficient accuracy in different meteorological conditions, especially in humid and moderate years.

Thus, the method we have developed to determine the moisture consumption of basic crops by the average daily evaporation provides a sufficiently high percentage of reliability of results and can be used to form the regime of irrigation of basic crops.

\section{CONCLUSIONS}

1. In the conditions of Southern Steppe, the use of water-saving regimes is most positively affected by cereals, soybean, alfalfa and potato, which under the reduction of the irrigation norm by $19.1-41.8 \%$, almost do not lose their yield.

2. The new method of the determination of the regime of irrigation of main crops with accordance to the indexes of daily evaporation is based on the requirements of plants to the water regime of soil taking into account the weather conditions of vegetation, meliorative conditions of the field, etc.

3. Comparative evaluation of the new estimation method with the most common in Ukraine for the determination of watering and irrigation norms in different weather conditions testifies about sufficiently high accuracy, and the results are close to those obtained directly in the field.

\section{SUMMARY}

The article presents the results of a study on the effects of irrigation regime types on crops productivity. Besides, a comparative evaluation of the new method of the vegetative watering assignment with others, most common in Ukraine, is provided.

It was determined that under the current conditions of economic management it is practically impossible to find an alternative to the watersaving model of the irrigation regime for crops. In the conditions of 
Southern Steppe, cereals, soybean, alfalfa and potato, which under the irrigation rate reduction by $19.1-41.8 \%$ almost do not lose their yields, reacted positively on the introduction of water-saving irrigation regimes.

Comparative evaluation of the new calculation method with the most common in Ukraine for the determination of irrigation and watering norms in different weather conditions testifies about a sufficiently high accuracy, and the obtained results are close to those got directly in the field where the balance-drier method was the standard.

\section{REFERENCES}

1. Авдеев Ю. И. Рекомендации по возделыванию сельскохозяйственных культур при капельном орошении. М.: Изд. МСХ РФ, 2003. $46 \mathrm{c}$.

2. Балюк С. А., Ромащенко М. І. Наукові аспекти сталого розвитку зрошення земель в Україні. К. : ДІА, 2006. 32 с.

3. Писаренко П. В., Вожегова Р. А., Лавриненко Ю. О., Коковіхін С. В. Вимоги сільськогосподарських культур до режиму зрошення. Посібник украӥнського хлібороба. 2011. С. 95-100.

4. Жовтоног О. І., Філіпенко Л. А., Шостак І. К., Поліщук В. В. Сучасна концепція та методи управління зрошенням на рівні господарства в умовах недостатнього зволоження. Наукові основи землеробства в умовах недостатнього зволоження. К., 2001. С. 89-92.

5. Жуйков Г. Є. Економічні засади ведення землеробства на зрошуваних землях. Херсон : Айлант, 2003. 288 с.

6. Кириенко Т. Н., Остапчик В. П., Жовтоног О. И. Основные принципы разработки почвозащитных режимов орошения. Oрошаемые черноземы и их рациональное использование. Новочеркасск: НПО «Мелиорация», 1990. С. 85-92.

7. Латифов Н. Л., Кобозев И. В., Парахин Н. В. Оптимизация режимов орошения сельскохозяйственных культур. М. : МСХА, 1996. $94 \mathrm{c}$.

8. Льгов Г. К., Адиньяев Э. Д. Водопотребление и режим орошения кукурузы. Агробиологическое обоснование поливного режима и применение удобрений под кукурузу. Тр. Горского СХИ. 1974. С. 3-37.

9. Методические указания по применению биофизического метода для определения эффективных запасов влаги в почве м сроков полмва сельскохозяйственных культур. Херсон: 1975. 77 с.

10. Писаренко В. А., Коковіхін С. В., Іванов І. Т., Тищенко О. П., Мішукова Л. С. та ін. Методичні рекомендації по застосуванню 
водозберігаючих режимів зрошення сільськогосподарських культур. Херсон : Айлант, 2002. 32 с.

11.Писаренко В. А. Методичні підходи до формування водозберігаючих режимів зрошення культур у степовому регіоні. Наукові основи землеробства в умовах недостатнього зволоження: Матер. наук.-практ. конф. 21-23 лютого 2000 р. К.: Аграрна наука, 2001. C. 181-189.

12. Писаренко В. А. Особливості планування режимів зрошення сільськогосподарських культур в умовах дефіциту водно-енергетичних ресурсів. Актуальні проблеми ефективного використання зрошуваних земель. Сб. наук. праць ін-т. зрошув. землер. Херсон, 1999. № 2. С. 8-12.

13. Розгон В. А. Оптимізація водного балансу зрошуваних територій. Зрошуване землеробство. 2002. № 3. С. 87.

14. Ромащенко М. І., Балюк С. А. Зрошення земель в Україні. Стан та шляхи поліпшення. К. : Світ, 2000. 114 с.

15. Ромащенко М. І., Жовтоног О. І., Філіпенко Л. А., Деменкова Т. Ф. Методика планування оптимальних екологічно безпечних режимів зрошення. К. : УкрНИИГиМ, 1997. С. 43.

16. Справочная книга по орошаемому земледелию. Общая ред.: Погребняк А.П., Калашников К.Г. Кишинев: Картя Молдовеняскэ. 1990. $134 \mathrm{c}$.

\section{Information about the author:} Pysarenko P. V., Doctor of Agricultural Science, Senior Researcher, Chief Researcher, Institute of Irrigated Agriculture of the National Academy of Agrarian Sciences of Ukraine Kherson, Naddniprianske, 73483, Ukraine 